Przegląd Prawa Konstytucyjnego

-----ISSN 2082-1212-----

DOI 10.15804/ppk.2021.05.49

-----Nr $5(63) / 2021-----$

Joanna Zofia Jagoda ${ }^{1}$

\title{
Glosa do wyroku Sądu Najwyższego z 28 listopada 2019 r., sygn. akt III CSK 275/17
}

Słowa kluczowe: odpowiedzialność odszkodowawcza, władza publiczna, samorząd terytorialny

Keywords: compensation responsibility, public authority, local government

\section{Streszczenie}

Teza wyrażona w glosowanym orzeczeniu, iż powiat ponosi wyłączną odpowiedzialność za szkodę spowodowaną wydaniem przez starostę wadliwej decyzji administracyjnej w ramach administracji architektoniczno-budowlanej, jest co do zasady słuszna. Jednak odpowiedzialność ta nie wynika - jak założył Sąd w komentowanym wyroku $\mathrm{z}$ charakteru zadań wykonywanych przez starostę, lecz z obecnych regulacji prawnych zawartych w kodeksie cywilnym (art. $417 \$ 2$ ). Błędne ustalenie charakteru zadań z zakresu administracji architektoniczno-budowlanej spowodowało oddalenie roszczeń odszkodowawczych wobec Skarbu Państwa i jednostki samorządu terytorialnego, mimo iż w okresie, gdy była podejmowana przedmiotowa decyzja o pozwoleniu na budowę, obowiązywał art. $420^{2}$ k.c., przewidujący odpowiedzialność solidarną Skarbu Państwa i jednostki samorządu terytorialnego za szkody wyrządzone przy wykonywaniu określonych ustawami zadań z zakresu administracji rządowej.

1 ORCID ID: 0000-0001-5740--815, doktor habilitowany, Instytut Nauk Prawnych, Wydział Prawa i Administracji, Uniwersytet Śląski w Katowicach. E-mail: joanna.jagoda@ us.edu.pl. 


\section{Abstract \\ Gloss to the Decision of the Supreme Court of 28 November 2019, file reference number III CSK 275/17}

The thesis expressed in the glossed judgment that the poviat bears sole responsibility for the damage caused by the issuing of a defective administrative decision by the starost as part of the architectural and construction administration is, in principle, correct. However, this responsibility does not result - as the Court assumed in the commented judgment - from the nature of the tasks performed by the starost, but from the current legal regulations contained in the Civil Code (Art. $417 \$ 2$ ). Incorrect determination of the nature of the tasks in the field of architectural and construction administration resulted in the dismissal of claims for damages against the State Treasury and local government unit despite the fact that at the time when the decision on the building permit was taken, Art. $420^{2}$ of the Civil Code, providing for joint liability of the State Treasury and of a local government unit for damages caused in the performance of government administration tasks specified by law, was in force.

\section{$*$}

\section{I.}

Tematyką glosowanego wyroku jest kwestia odpowiedzialności władzy publicznej za szkody wyrządzone wadliwą decyzją administracyjną. Sąd Najwyższy stwierdził, iż za szkodę spowodowaną wydaniem przez starostę wadliwej decyzji administracyjnej w ramach administracji architektoniczno-budowlanej odpowiada powiat.

II.

Glosowane orzeczenie zapadło na kanwie następującego stanu faktycznego. Prezydent Miasta K. (miasta na prawach powiatu) zatwierdził projekt budowlany i wydał pozwolenie na budowę. Następnie Wojewoda, jako organ odwoławczy, stwierdził nieważność decyzji organu I instancji. Decyzja ta zosta- 
ła utrzymana w mocy wyrokiem Wojewódzkiego Sądu Administracyjnego, a następnie Naczelnego Sądu Administracyjnego. Osoby poszkodowane wydaniem wadliwej decyzji administracyjnej w sprawie pozwolenia na budowę wniosły pozew o odszkodowanie za szkodę spowodowaną wydaniem decyzji o pozwoleniu na budowę dotkniętej wadliwościami skutkującymi następnie stwierdzeniem jej nieważności. Pozew został skierowany wobec Gminy Miejskiej K. i Skarbu Państwa - Prezydenta Miasta K.

Sądy powszechne obu instancji, a następnie Sąd Najwyższy w glosowanym wyroku uznały, że starosta wydając decyzję o pozwoleniu na budowę realizuje zadania własne powiatu i działa w ramach imperium przysługującego powiatowi jako jednostce samorządu terytorialnego. Oznacza to, że za działania powiatu realizowane w ramach zadań własnych, Skarb Państwa nie ponosi odpowiedzialności. Oddalając skargę kasacyjną Sąd stwierdził jednocześnie, że roszczenia kierowane wobec Gminy Miejskiej K. uległy przedawnieniu. W rezultacie poszkodowani decyzją w sprawie pozwolenia na budowę zostali pozbawieni jakiegokolwiek odszkodowania, zarówno od Skarbu Państwa, jak i od jednostki samorządu terytorialnego.

\section{III.}

Teza wyrażona w glosowanym orzeczeniu, iż powiat ponosi wyłączną odpowiedzialność za szkodę spowodowaną wydaniem przez starostę wadliwej decyzji administracyjnej w ramach administracji architektoniczno-budowlanej, jest co do zasady słuszna. Jednak odpowiedzialność ta nie wynika - jak założył Sąd w komentowanym wyroku - z charakteru zadań wykonywanych przez starostę (które według Sądu są zadaniami własnymi powiatu), lecz z obecnych regulacji prawnych zawartych w kodeksie cywilnym (art. $417 \$ 2$ k.c.). Błędne ustalenie charakteru zadań z zakresu administracji architektoniczno-budowlanej spowodowało oddalenie roszczeń odszkodowawczych wobec Skarbu Państwa i jednostki samorządu terytorialnego, mimo iż w okresie, gdy była podejmowana przedmiotowa decyzja o pozwoleniu na budowę, obowiązywał art. $420^{2}$ k.c., przewidujący odpowiedzialność solidarną Skarbu Państwa i jednostki samorządu terytorialnego za szkody wyrządzone przy wykonywaniu określonych ustawami zadań z zakresu administracji rządowej. 
$\mathrm{Na}$ tle glosowanego wyroku pojawia się zatem kilka kwestii dotyczących odpowiedzialności odszkodowawczej władzy publicznej, które wymagają komentarza. Niewłaściwa interpretacja przepisów dotyczących tej odpowiedzialności może bowiem prowadzić do pozbawienia obywateli jednego z podstawowych praw, jakim jest prawo do wynagrodzenia szkody, jaka została wyrządzona przez niezgodne z prawem działanie organu władzy publicznej (art. 77 Konstytucji ${ }^{2}$ ).

W pierwszej kolejności należy zwrócić uwagę, że glosowane orzeczenie zostało wydane na podstawie błędnego założenia, iż starosta wydając decyzję o pozwoleniu na budowę, czyni to w imieniu własnym powiatu i na jego odpowiedzialność, ponieważ decyzje wydawane w ramach administracji architektoniczno-budowlanej są przejawem realizowania zadań własnych powiatu. Założenie to jest sprzeczne z utrwaloną linią orzeczniczą sądów administracyjnych ${ }^{3}$, a ponadto odbiega od poglądów wyrażanych w doktrynie prawa administracyjnego. Administracja architektoniczno-budowlana jest jednym z zadań publicznych o charakterze ponadgminnym powiatu (art. 4 ust. 1 pkt 11 u.s.p. ${ }^{4}$ ). Zgodnie z art. 4 ust. 4 u.s.p., ustawy mogą określać niektóre sprawy należące do zakresu działania powiatu jako zadania z zakresu administracji rządowej wykonywane przez powiat. W przepisach prawa budowlanego ${ }^{5}$ brak przepisu, który określałby zadania z zakresu administracji architektoniczno-budowlanej jako zadania z zakresu administracji rządowej, tak jak np. zostało to określone w art. 11 ust. 1 ustawy o gospodarce nieruchomościami ${ }^{6}$ czy też w art. 3 ust. 1 ustawy o scalaniu i wymianie gruntów ${ }^{7}$. Należy jednakże zauważyć, że po odtworzeniu w Polsce samorządu terytorialnego (27 maja 1990 r.) sprawy z zakresu prawa budowlanego należały do or-

2 Konstytucja Rzeczypospolitej Polskiej z 2 kwietnia 1997 r. (Dz.U. Nr 78, poz. 483 ze zm.), dalej: Konstytucja.

3 Por. postanowienia NSA z: 16 września 2011 r. (II OW 76/11), 15 lipca 2011 r. (II OW 50/11), 22 października 2010 r. (II OW 52/10), 11 marca 2011 r. (II OW 106/10), 7 kwietnia 2011 r. (II OW 107/10), 7 kwietnia 2011 r. (II OW 10/11).

4 Ustawa z 5 czerwca 1998 r. o samorządzie powiatowym (t.j. Dz.U. 2020, poz. 920), dalej: u.s.p.

5 Ustawa z 7 lipca 1994 r. Prawo budowlane (t.j. Dz.U. 2020, poz. 1333), dalej: Pr. bud.

6 Ustawa z 21 sierpnia 1997 r. o gospodarce nieruchomościami (t.j. Dz.U. 2020, poz. 1990).

Ustawa z 26 marca 1982 r. o scalaniu i wymianie gruntów (t.j. Dz.U. 2018, poz. 908). 
ganów administracji rządowej. W ustawie z 17 maja 1990 r. o podziale zadań i kompetencji określonych w ustawach szczególnych pomiędzy organy gminy a organy administracji rządowej oraz o zmianie niektórych ustaw ${ }^{8}$, zadania i kompetencje dotychczasowych organów administracji państwowej wynikające z wówczas obowiązującej ustawy z 24 października 1974 r. - Prawo budowlane stały się zadaniami i kompetencjami organów administracji rządowej (nieobowiązujące już art. 5 pkt 16 oraz art. 6 pkt 6 powołanej ustawy z 17 maja 1990 r.). Następnie, po wejściu w życie obecnie obowiązującej ustawy Prawo budowlane (1 stycznia 1995 r.) do czasu wejścia w życie ustawy o samorządzie powiatowym (1 stycznia 1999 r.) zadania, które wykonuje obecnie starosta jako organ administracji architektoniczno-budowlanej, także należały do zadań organów administracji rządowej.

Do 31 grudnia 1998 r. zadania określone w przepisach prawa budowlanego wykonywały organy państwowego nadzoru budowlanego, które dzieliły się na nadzór architektoniczno-budowlany oraz specjalistyczny nadzór budowlany. Zgodnie z art. 84 ust. $1 \mathrm{w}$ brzmieniu obowiązującym do 1 stycznia 1999 r., terenowymi organami nadzoru architektoniczno-budowlanego byli wojewoda i kierownik urzędu rejonowego, przy czym ten ostatni był organem pierwszej instancji, o ile ustawa nie stanowiła inaczej.

Ustawą z 24 lipca 1998 r. o zmianie niektórych ustaw określających kompetencje organów administracji publicznej - w związku z reformą ustrojową państwa ${ }^{9}$, która weszła w życie 1 stycznia 1999 r., zmieniono rozdział 8 prawa budowlanego w ten sposób, że w miejsce państwowego nadzoru budowlanego utworzono administrację architektoniczno-budowlaną i nadzór budowlany, powierzając zadania administracji architektoniczno-budowlanej Głównemu Inspektorowi Nadzoru Budowlanego, wojewodzie oraz staroście. 1 stycznia 1999 r. weszła w życie także ustawa o samorządzie powiatowym, w której, jak już wspomniano, zadania $\mathrm{z}$ zakresu administracji architektoniczno-budowlanej określono jako zadania publiczne o charakterze ponadgminnym.

Natomiast w ustawie z 13 października 1998 r. - Przepisy wprowadzające ustawy reformujące administrację publiczną ${ }^{10}$ przyjęto zasadę, że urzędy rejonowe stają się starostwami (art. 14 ustawy), oraz zawarto przepis (art. 94

\footnotetext{
$8 \quad$ Dz.U. Nr 34, poz. 198.

9 Dz.U. Nr 106, poz. 668.

10 Dz.U. Nr 133, poz. 872.
} 
ustawy), według którego do właściwości starosty przechodzą, jeżeli przepisy szczególne nie stanowią inaczej, jako zadania z zakresu administracji rządowej, określone w przepisach zadania urzędów rejonowych rządowej administracji ogólnej oraz zadania i kompetencje kierowników tych urzędów. Te uregulowania mogłyby świadczyć, że zadania powiatu z zakresu administracji architektoniczno-budowlanej są, niejako na zasadzie sukcesji, zadaniami administracji rządowej. ${ }^{11}$

Zauważyć też należy, że zarówno art. 4 ust. 4 u.s.p., jak i art. 2 pkt 5 ustawy z 23 stycznia 2009 r. o wojewodzie i administracji rządowej w województwie ${ }^{12}$ dla uznania, że zadania powiatu należą do zadań z zakresu administracji rządowej, lub do przyjęcia, że starosta wykonuje zadania z zakresu administracji rządowej, wymagają przepisu ustawy. Za taki przepis ustawy można uznać art. 94 ww. ustawy - Przepisy wprowadzające ustawy reformujące administrację publiczną, przyjmując, że starosta wykonuje zadania z zakresu administracji rządowej, uzyskane w drodze „sukcesji”"13.

\section{IV.}

Przy ocenie charakteru omawianych kompetencji starosty należy także wziąć pod uwagę strukturę organizacyjną organów odwoławczych w administracji architektoniczno-budowlanej. Organem odwoławczym w stosunku do starosty działającego jako organ administracji architektoniczno-budowlanej jest wojewoda, a zatem organ należący do struktury organów rządowych, a nie samorządowych. Zgodnie z art. 17 pkt 1 i pkt 3 kodeksu postępowania administracyjnego ${ }^{14}$, organami wyższego stopnia w stosunku do organów jednostek samorządu terytorialnego są, co do zasady, samorządowe kolegia odwoławcze. Artykuł 82 ust. 3 Pr. bud. modyfikuje jednak tę zasadę, stanowiąc, że organem administracji architektoniczno-budowlanej wyższego stopnia w sto-

11 Z. Kostka, Komentarz do art. 80 (uwaga 4), [w:] Prawo budowlane. Komentarz, wyd. III, red. A. Gliniecki, Warszawa, WK/el. 2016.

12 T.j. Dz.U. 2019, poz. 1464.

13 Tak W. Jakimowicz, Decyzja o pozwoleniu na budowę jako przejaw realizowania przez starostęzadań z zakresu administracji rzadowej, „Casus” 2016, nr 80, s. 6-12.

14 Ustawa z 14 czerwca 1960 r. Kodeks postępowania administracyjnego (t.j. Dz.U. 2021, poz. 735$)$, dalej: k.p.a. 
sunku do starosty jest wojewoda. Ponadto z art. 82 ust. 3 i 4 Pr. bud. wynika, że dla niektórych obiektów i robót budowlanych organem pierwszej instancji jest wojewoda, a więc organ administracji rządowej i przedstawiciel Rady Ministrów w województwie. Wydaje się, że ustawodawca nie powierzyłby wojewodzie do realizacji w pierwszej instancji zadań należących do samorządu terytorialnego. Wojewoda nie wydawałby np. pozwoleń na budowę w pierwszej instancji, gdyby nie były to zadania rządowe. Należy ponadto przywołać art. 15 ust. 1 ustawy z 20 października 1994 r. o specjalnych strefach ekonomicznych ${ }^{15}$, który wprost przewiduje, że starosta wykonując zadania z zakresu prawa budowlanego wykonuje zadania z zakresu administracji rządowej.

Mając powyższe na uwadze, nie powinno ulegać wątpliwości, iż zadania administracji architektoniczno-budowlanej są zadaniami zleconymi z zakresu administracji rządowej, a nie zadaniami własnymi powiatu. Oznacza to, że do czasu uchylenia przepisu art. $420^{2}$ k.c. (1 września 2004 r. ${ }^{16}$ ) odpowiedzialność odszkodowawczą za wadliwe decyzje podjęte przez starostę (prezydenta miasta na prawach powiatu), których nieważność stwierdził organ II instancji (wojewoda), ponosili solidarnie Skarb Państwa i właściwa jednostka samorządu terytorialnego (powiat lub miasto na prawach powiatu).

V.

$\mathrm{W}$ art. $417 \$ 2$ k.c. przyjęto odmienne rozwiązania od obowiązujących uprzednio w art. $420^{2}$ k.c., który stanowił, że jeżeli szkoda została wyrządzona przez funkcjonariusza jednostki samorządu terytorialnego przy wykonywaniu określonych ustawami zadań z zakresu administracji rządowej lub zleconych przez ustawy albo powierzonych, odpowiedzialność za szkodę ponoszą Skarb Państwa i jednostka samorządu terytorialnego solidarnie. Artykuł $420^{2}$ odnosił się tylko do zlecenia jednostce samorządu terytorialnego wykonywania zadań z zakresu administracji rządowej i przewidywał solidarną odpowiedzialność Skarbu Państwa i jednostki samorządu terytorialnego za wyrządzoną szkodę, niezależnie od tego, czy powierzenie nastąpiło na podstawie ustawy,

$15 \quad$ T.j. Dz.U. 2020, poz. 1670.

16 Art. $420^{2}$ k.c. został uchylony ustawą z 17 czerwca 2004 r. o zmianie ustawy - Kodeks cywilny oraz niektórych innych ustaw (Dz.U. Nr 162, poz. 1692). 
czy porozumienia. Tymczasem zgodnie z art. 166 ust. 2 Konstytucji, jeżeli wynika to z uzasadnionych potrzeb państwa, ustawa może zlecić jednostce samorządu terytorialnego wykonywanie innych zadań publicznych (obok zadań własnych, o których stanowi art. 166 ust. 1 Konstytucji), zgodnie zaś z art. 16 ust. 2 Konstytucji: „Przysługującą mu [tj. samorządowi terytorialnemu - przyp. aut.] w ramach ustaw istotną część zadań publicznych samorząd wykonuje w imieniu własnym i na własną odpowiedzialność". Istniała zatem wątpliwość, czy art. $420^{2}$ k.c. pozostawał w zgodzie z postanowieniami Konstytucji ${ }^{17}$.

Artykuł 16 ust. 2 Konstytucji determinował zatem rozwiązania przyjęte w art. 417 k.c. Jeżeli źródłem wykonywania przez jednostkę samorządu terytorialnego zadań z zakresu administracji publicznej, a dokładniej z zakresu administracji rządowej, jest ustawa, to odpowiedzialność za szkodę wyrządzoną przez niezgodne z prawem działanie lub zaniechanie przy wykonywaniu tego zadania ponosi wyłącznie jednostka samorządu terytorialnego. Jeśli zaś źródłem wykonywania zadania z zakresu administracji rządowej przez jednostkę samorządu terytorialnego jest porozumienie, to za wynikłą szkodę ponoszą solidarną odpowiedzialność Skarb Państwa i jednostka samorządu terytorialnego. Te same reguły dotyczą innej osoby prawnej, która wykonuje zadania z zakresu władzy publicznej bądź na podstawie ustawy, bądź na mocy porozumienia ze Skarbem Państwa lub jednostką samorządu terytorialnego.

\section{Literatura}

Bagińska E., Odpowiedzialność odszkodowawcza za wykonywanie władzy publicznej, Warszawa 2006.

Bagińska E., Węzłowe problemy odpowiedzialności deliktowej jednostek samorządu terytorialnego w świetle najnowszego orzecznictwa, „Gdańskie Studia Prawnicze” 2015, nr 2.

Cebera A., Odpowiedzialność odszkodowawcza za niezgodne z prawem działania organów administracji publicznej, Warszawa 2018.

Gudowski J., Bieniek G., Komentarz do art. 417 (uwaga 31), [w:] Kodeks cywilny. Komentarz, t. III, Zobowiązania. Część ogólna, wyd. II, red. J. Gudowski, Warszawa 2018.

17 J. Gudowski, G. Bieniek, Komentarz do art. 417 (uwaga 31), [w:] Kodeks cywilny. Komentarz, t. III, Zobowiązania. Część ogólna, wyd. II, red. J. Gudowski, Warszawa, WKP/el. 2018. 
Jakimowicz W., Decyzja o pozwoleniu na budowe jako przejaw realizowania przez starostę zadań z zakresu administracji rządowej, „Casus” 2016, nr 80.

Karaszewski G., Komentarz do art. 417, [w:] Kodeks cywilny. Komentarz, red. J. Ciszewski, red. P. Nazaruk, Warszawa 2019.

Kostka Z., Komentarz do art. 80 (uwaga 4), [w:] Prawo budowlane. Komentarz, wyd. III, red. A. Gliniecki, Warszawa 2016.

Szczepaniak R., Odpowiedzialność odszkodowawcza jednostek samorządu terytorialnego, Warszawa 2001. 